\title{
Creating a Violent-Free Culture in Nigeria: A Child Rearing Approach
}

\author{
Charity O. Igbokwe, Rosemary C. Piate, Boniface Akpan \\ Akwa Ibom State College of Education, Afaha Nsit, Nigeria
}

\begin{abstract}
The family is the foundation of the society. If the product of the family is bad, its effect in the society could often be adverse or brutal. The early experiences of a child in terms of the degree of care, type of control, and emotional tone of the home is formative, contribute to the child's temperament and influence his/her behaviour later in life. These early experiences of a child depend on his/her parents' child rearing practices, which in turn depend on some family variables and characteristics. Using available literature, this article identified influence of violent or aggressive role models, single and step-parenting environment, and low educational and class status of parents as some of the family factors or characteristics with a wide range of adverse effect on children's well-being and which can lead to varied anti-social behavior, such as aggression or violence in the individual. It was recommended among other things that for effective child rearing practices by parents and families, interventions that could increase the number of children reared by continuously married biological parents should be encouraged. Recommendations that could make for good child rearing practices and therefore stem the tide of violent behaviour in Nigeria in the long run were made.
\end{abstract}

Keywords: violence, child rearing, family structure, parent type

\section{Introduction}

In recent times, much concern has been expressed about Nigeria's continued survival as a nation because of violence. For example, Enweremadu (2014) reported that since its return to civil rule in May 1999, many parts of the country, especially the oil producing Niger Delta region, have drifted from one violent conflict to another, often with devastating consequences on human life and socio-economic development, partly because of skewed revenue sharing formula and the predatory nature of politics in Nigeria, as seen in the accumulative instinct of public officials at all levels of government and the increasing determination of "renegade actors" to violently challenge their quest to monopolize resources accruing from oil.

The militant Islamist movement Boko Haram is active in northern Nigeria. Vangard (2014) reported that the Boko Haram insurgency has left more than 10,000 dead and displaced more than 650,000 over the past five years, notable among which was the seizure of 276 young girls from their school in the remote town of Chibok in Borno State, northeast Nigeria, on April 14, 2014, out of which 57 of the girls managed to flee. Africa Report (2014) disclosed that Boko Haram insurgency has pitted neighbour against neighbour, destroyed

Charity O. Igbokwe, Ph.D., lecturer I, Department of Early Childhood Education, Akwa Ibom State College of Education. Rosemary C. Piate, M.Ed., senior lecturer, Department of Primary Education, Akwa Ibom State College of Education. Boniface Akpan, M.Ed., lecturer II, Department of Primary Education, Akwa Ibom State College of Education. 
hundreds of schools and government buildings and devastated an already ravaged economy in the North East, one of Nigeria's poorest regions; while the Nigeria Security Tracker (NST) (2014) lamented that some forms of the violence are motivated by political, economic, or social grievances and they are such that violence among ethnic groups, farmers, and herdsmen sometimes acquires religious overtones. Also, soldiers kill civilians indiscriminately while police are notorious for extrajudicial murder.

The Centre for Law Enforcement Education (CLEEN) Foundation (2014) describing domestic violence as another dimension of violence in Nigeria reported that it is widespread, shows no signs of lessening in Nigeria, has increased nationwide in the past three years from $21 \%$ in 2011 to $30 \%$ in 2013 , takes many forms including physical, sexual, emotional, and mental, and manifests in rape, acid attacks, molestation, wife beating, and corporal punishment.

Abayomi (2003) raised alarm over the emergence of ethnic militias and self-determination groups, which has continued to gain momentum as a marked dimension of violence in Nigeria. Notable amongst these are O'odua People's Congress (OPC), Arewa People's Congress (APC), Onitsha Traders Association (OTA), Bakassi Boys, Federated Niger Delta Ijaw Communities (FNDIC), Egbesu Boys of Africa (EBA), Niger Delta Volunteer Force (NDVF), Niger Delta Vigilante (NDV), Niger Delta People's Volunteer Force (NDPVF), Hisbah groups, Zamfara State Vigilante Service (ZSVS), and Al-Sunna Wal Jamma (otherwise referred to as "Taliban"). The primary implication of this is that predominant populations of the youths have been absorbed into these groupings. While the Nigeria Watch (2012) reported that between June 1, 2006 and May 31, 2011, there were 7,645 incidents of violence resulting in 30,373 deaths, the NST (2014) disclosed that between June 12, 2011 and August 31,2014, the total number of deaths due to violence was 21,394. Abayomi (2003) has expressed serious concern and worries that deployment of small arms and light weapons in violent conflicts in Nigeria appears to be on the increase. Provoked by these large-scale violence, government largely adopt military response, provision of relief materials to victims, resettlement of some displaced survivors of violence, and sometimes negotiation with perpetrators of violence. These measures appear to be adhoc and produce only short-term effect, hence, result in the spate of violence. The kernel of this paper is that sound and proper child rearing practices at infancy by families and parents will be a more sustainable and long-term answer to building a violent-free culture in Nigeria.

Wendorf (2004) warned that we, as parents, literally have in our hands the ability to create a violent culture or a peaceful one. The degree of care and love that a child receives in the early years dictates the child's sense of relationship to the society and to himself/herself. A child cannot care for or nurture others if he/she is not cared for or nurtured first. The problem of violence in Nigeria can be traced back to the socialization process of the child in his/her early years of life.

This is because the degree of child neglect and lack of sound child rearing practices by parents in Nigeria is an issue of immense concern. Hence, Prescott (2010) had observed that when deprived of nurturing, almost $100 \%$ of orphans in the early 20 th century died. Even when provided with adequate caloric intake, infants who are denied human touch often still fail to grow and thrive and that the main cause of human violence is "a lack of touching and stroking during the formative periods of life". Yet, the same parents bemoan the poor behavior of their children of today. They forget that they had a major role in the rearing and education of the children they now depreciate. Hence, Hoffman (1963) and Bornstein (2002) asserted that bad fruit and failure being reaped today date back to bad seed sown by parents, especially during the formative years. Arnold et al. (1975) cautioned that although parents are sensitive to their children's growth, but more concern should be shown over 
the affairs of the children and the direction which growth is taking. Therefore, guidance is needed in the early years of learning when foundation is being laid. Persistent failure of parents to provide guidance and meet a child's basic physical and psychological needs is likely to cause death or impair the child's health and moral and social development. Such needs include providing food or shelter, adequate protection from danger, and medical care and avoiding emotional neglect. Obviously, the amount and effectiveness of the guidance received by the children at this stage from the parents depend on the child rearing practices of the parents.

\section{Child Rearing}

Child rearing refers to bringing up children by parents or parent substitutes (Saramma \& Thomas, 2010). That is, child rearing describes the way parents bring up their children. It consists of practices derived from cultural patterns and beliefs. According to Iliya (2000), it includes the type of control, degree of care, and emotional tone of the home. It is probably the most challenging responsibility for parents during their children's infancy. Evans and Myers (1994) remarked that successful child rearing is essential for children's overall development and realization of self-esteem. In line with this view, Darling and Steinberg (1993) said that how a child is raised or the parenting style influences the child's behaviour and psychological development and affects how successful he/she can be later in life. When an infant is a newborn, parenting involves caring for his/her basic needs, but as a child progresses through infancy to his/her first birthday, parenting differs among families. The early experiences with child rearing are formative and contribute to the child's temperament as he/she grows up.

The psychologist Baumrind (1966) developed five main strategies of child rearing typical of parenting styles, namely, attachment, permissive, authoritarian, authoritative, and uninvolved parenting styles (for more details, see the reference therein). Each parenting style has benefits and uses, and while one style may be more favoured in one culture, no style is necessarily the correct way to parenting. Each style is adapted and changed by parents as the child grows. Differences among the parenting styles lie mainly in whether a parent creates many or few rules for his/her child and whether a parent is emotionally responsive or neglectful. Whatever parenting style is used, some researchers (Harris,1988; Reeve, 1992; Bruer, 1999) have warned that the critical issue in child rearing is for caregivers to meet the needs of the infant.

In Africa, even though other elder members of the family also contribute to child care, the mother is the primary caregiver for infants (Armar-Klemesu, Reul, Maxwell, Levin, \& Morris, 2000). In fact, the important components of child care at infancy are maternal activities that promote children's physical, intellectual, and psycho-social development so that they may grow up to express their full potentials. Hence, Saramma and Thomas (2010) identified the major domains or constructs of child rearing during infancy as feeding, meeting the needs of cleaning and protection, including prevention of accidents and injuries, providing appropriate infant stimulation, and monitoring growth and development.

Also, the recommendations on the five components of child rearing practices are summarily captured in World Health Organisation (WTO) Early Childhood Development Task Team document endorsed at the 2000 Durban inter-agency meeting on "Improving Children's Health and Nutrition in Communities". It recommended for promotion at family and community levels as part of integral approach to child survival, growth, and development. It states as follows:

1. Breastfeed exclusively for six months (taking into account WHO/UNICEF/UNAIDS policy and recommendation on HIV and infant feeding); 
2. Starting about six months of age, feeding children freshly prepared energy and nutrient-rich complementary foods, while continuing breastfeeding up to two years or longer;

3. Providing children with adequate amount of micronutrient (Vitamin A and iron in particular), either in their diet or through supplementation;

4. Promoting child mental and social development by being responsive to the child's need for care, and stimulating the child through talking, playing, and other appropriate physical affective interaction;

5. Taking children as schedule to complete a full course of immunization (Bacille Calmette-Guérin (BCG), Diphtheria-Pertussis-Tetanus Vaccine (DPT), Oral Poliomyelitis Vaccine (OPV), and measles);

6. Dispose of faeces (including children faeces) and washing hand with soap after defecation and before preparing meals and feeding children;

7. In malaria-endemic areas, ensuring children sleep under recommended insecticide treated mosquito nets;

8. Adopting and sustaining appropriate behaviour regarding the prevention and care for HIV/AIDS affected people, including orphans;

9. Continuing to feed and offer more fluids to children when they are sick;

10. Giving sick children appropriate home treatment for illness;

11. Recognized when sick children need treatment outside the home and take them for health care appropriate providers;

12. Ensuring that every pregnant woman receives the recommended four antenatal visits, recommended doses of tetanus toxoid vaccination, and is supported by family and community in seeking appropriate care, especially at time of delivery and during the postpartum/lactation period;

13. Following recommendation given by health workers, nutritionists, and community-based workers in relation to treatment, follow-up and referral, completion of immunisation, sleeping under bed nets , and feeding advice;

14. Taking appropriate action to prevent and manage child injuries and accidents. (WHO, 2000)

\section{Theoretical Motivations}

This article is based on the following theories: (a) Maslow's theory of Hierarchy of Needs; and (b) Albert Bandura's Social Learning Theory.

\section{Abraham Maslow's Theory of Hierarchy of Needs}

The role of parents in providing their children with basic needs through child rearing practices is very crucial in bringing up children. Wendorf (2004) recognized this role, and according to him, a baby whose needs are consistently met by positively relaxed parents who also understand him/her learns that he/she can rely on people. Furthermore, the child learns that he/she has a voice. He/she learns that he/she can try new things, since he/she will be supported as he/she stumbles along on his/her quest for independence. This early parental safety attention builds trust, confidence, and empathy.

Maslow (1970), in his theory of Hierarchy of Needs, utilized in a variety of contexts which are readily applicable to a growing baby, emphasized five levels of human development for the attention of parents especially at the early age when they are not yet capable of providing for any of these needs themselves (Campbell, 2014). These needs are associated with early child care practices that any modern family has to apply. Maslow wanted to understand why certain people are successful. Maslow in his Hierarchy of Needs visualized in a pyramid, explained the spectrum of human needs, from basics, like food, to complex social needs, like respect. He theorized that a person could not achieve higher needs without satisfying basic ones.

Maslow postulated that all humans had basic needs, and that until those needs were met, all other needs would be perceived as subsets of those needs. Therefore, a person who was cold, hungry, homeless, and friendless might simply describe himself/herself as hungry.

Maslow's Hierarchy of Needs can be broken down into two categories: the instinctual needs and the 
growth needs. The first four levels on Maslow's hierarchy, the instinctual needs, are the most applicable to babies and children. These are the needs that, if not fulfilled, will gain importance and focus as a child becomes highly compelled to fill them (Campbell, 2014). The levels, which fall into the instinctual needs category, are physiological, safety and security, social needs, and esteem.

Physiological. The first instinctual need is the physiological needs which include nutrition, oxygen, hydration, shelter, rest, and human touch. This level involves meeting an infant's most basic needs so that he can be nurtured to a higher stage of development. Without meeting these needs, an infant will likely suffer from a failure to thrive, and he/she will not be able to develop trust in his/her caregivers (Campbell, 2014). Physiological need is associated with psychological development of children and at the same time helps them prepare for preschool or primary school education. The needs for food, shelter, and warmth are the basic needs to be provided by parents for the survival of the child. Failure to provide these basic needs will affect children's physical development and thus reduce their ability to prepare for preschool and primary school later on.

Safety and security. Maslow (1970) wrote that once a person's basic needs were met, the person would then turn attention to other needs. Babies become concerned with this second stage, safety and security, once they are confident that their physiological needs have been met and will continue to be met. This is the stage where structure becomes important and when a child is most likely to begin expressing fear or worry (Campbell, 2014). By three months of age, babies will respond to familiar faces and smile at a primary caregiver and calm when held, showing that they feel secure. At this safety and security level, parents need to protect their children from danger and maintain a safe and stable environment.

Social needs. Maslow stated that once a person was fed, sheltered, and safe, the person would respond with affection toward those around. He noted that this was especially true of children, who would give their trust to adults who saw to their well-being. Hence, a one-year-old might become very upset upon being separated from his/her mother, indicating that the bonds of affection would be very strong by this age (Campbell, 2014).

This level on the hierarchy involves a child's need to feel unconditional love and acceptance. Children must first feel family stability at the safety and security level before they can begin seeking social interaction outside of the family. For a baby, this is the stage when distrust in strangers and separation anxiety should begin to fade as comfort in the family structure increases. Babies will become more open to exploring and playing, as well as interacting readily with others. This third basic need is a challenge to parents to provide love and emotional support to their children. The way parents express love to their young children may be different, some may use more verbal communication, such as praises, reprimands, and discussions to convey their love and concern about certain accepted or unaccepted behavior; others may use non-verbal signals, such as giving treats and gifts for accepted behavior and punishment and rejection to unaccepted acts by the child. These practices can be effective and sometimes may be rejected under particular circumstances. Some families lack emotional or social ability to provide those basic needs. Divorce, death of spouse, illness, substance abuse, unemployment, bankruptcy, and other upheavals in a family are likely to produce negative impact on emotional support and intimacy (Hetherington \& Kelly, 2002).

Self-esteem. Once a person has his/her physical needs satisfied, he/she feels safe and he/she is loved. Now the person has a need to make a place for himself/herself in the world by getting a job, earning awards, or mastering a trade. He/she wants to be respected by his/her peers. The esteem level on the Maslow Hierarchy of Needs will occur when a baby enters childhood. This is the stage when the baby will begin to focus on his/her 
own self-worth. Between age nine months and age three, a baby makes tremendous strides toward mastering his/her world. A secure baby explores his/her world and he/she is confident that his/her achievements will be admired (Campbell, 2014). Encouragement and respect are important, as well as positive discipline and the opportunity to learn life skills. During this tier, children will begin to build upon confidence and independence. At this level, Maslow's hierarchy of children's basic needs emphasize the duty of parents to promote self-esteem and support achievements in their younger children. Some may use reward and others may use praise, but there are also parents who like to compare among siblings and other children of relatives, neighbors, or friends. Parents sometimes demand that their children achieve standards and meet expectations to perform certain tasks especially in academics. These expectations can cause frustration and aggression if children fail to perform as expected by their parents.

Self-actualization. When a person has achieved real world mastery, he/she needs something more. This is the stage at which people fulfil dreams or carve out inner peace for themselves. Some types of fulfillment are unlikely for young children, but when they are secure and happy, they love to pursue creative endeavours (Campbell, 2014). Building with blocks, painting pictures or making mounds in a sandbox may come under this heading. They feel secure from criticism and engage in imaginative play. This tier of Maslow's Hierarchy of Needs requires parents to support their children's growth with self-actualization. Parents should inculcate in their children a sense of responsibility and guide them to solve problems in critical situations; foster readiness for children to grow up independently as special individuals and make their own decision at the appropriate levels of growth and ability; and not compare one child with another because each child has his/her own strengths and weaknesses.

Fulfilling all these basic needs may vary from family to family, and from parent to parent, depending on the child rearing practices of such families and parents.

According to the above Hierarchy of Needs, a child without adequate nourishment cannot strive for affection and a sense of belonging; he/she is physiologically stuck in the first level of development. A child who never received consistent love is incapable of striving for self-respect and the respect of others, as these needs rely first on the ability to give and receive love. Maslow further proposed that self-actualized, conscious people are naturally connected to the world, have the capacity to be concerned with global issues, and can appreciate the beauty in nature and in living and hence would be emotionally touched to be associated with violence.

\section{Implications of Maslow's Theory to Child Rearing}

If Maslow's theory holds true, as evidence seems to indicate, proponents of attachment parenting are making invaluable strides to improve the future of society. And, as Wendorf (2004) asserted, "If bonding in the early years dictates a child's sense of his/her relationship to the world and himself/herself, then baby-parent bonding is critical in the development of both strong individuals and ultimately, a peaceful, harmonious community". Consistent response to the baby's needs; smoother parent-baby interactions; ability to read the baby's cues and anticipate his/her needs; and inclusion of the baby in parents' daily social interactions contribute to an infant's sense of trust, confidence, and security. A confident baby who receives consistent, unconditional love and whose needs are respected and met is able to become a caring, considerate, and independent member of society. Wendorf (2004) warned that we, as parents, literally have in our hands the ability to create a violent culture or a peaceful one, depending on how we rear our children. Our future rests in 
the hands of the children we raise, the values we impart on them, and the way they learn to perceive their relationship with the world. The survival of our world is determined by how we choose to raise our children.

In order to change the destructive path we are currently on in Nigeria: violence, corruption, criminality, fraud, lawlessness, and others, we need to cherish our young, nurture and help them maintain their connection to humanity, and ultimately, to the society. A child cannot care for others if he/she is not cared for first. He/she cannot nurture another without being nurtured himself/herself. Children who mature without these basic needs become adults incapable of giving unconditional love, support, and sympathy.

Hence, as earlier stated, Prescott (2010) reported that when deprived of nurturing, caring, and human touch, almost $100 \%$ of orphans in the early 20 th century died. Even when provided with adequate caloric intake, infants who are denied human touch often still fail to grow and thrive, and furthermore that the main cause of human violence is lack of "touching and stroking during the formative periods of life".

We therefore need to return to our natural, biological, and instinctive way of parenting. Babies are born utterly dependant, unable to eat, speak, or move without assistance. They are also emotionally dependent on their parents to affirm their existence, to regulate their emotional responses, and to model appropriate love and attachment. It is in the consistency of this relationship that babies learn to feel safe, to trust others, and ultimately, to trust themselves and become independent and self-assured. This autonomy, security, and confidence enable babies to grow into children and adults who can afford to look beyond themselves and their own needs. A person who is loved can give love; a person who is supported can assist others. These are the people we need in Nigeria - loved, supported, nurtured, and independent- to care for our society and our future; and not victims or products of poor child rearing practices who are socially maladjusted and whose direction in life is to unleash violence in the society. Therefore, the important lesson to learn from Maslow's theory of Hierarchy of Needs is that the functions of parents and families in providing basic care for their children for the future well-being of society need to be re-emphasized.

\section{Albert Bandura's Social Learning Theory}

According to W. D. Rohwer, G. R. Rohwer, and Howe (1980), social learning involves other persons in the use of discriminations, motor skills, concepts, rules, procedures, and attitudes. In social learning, changes in behaviour and thought can result from observing models in the world around us, for instance, parents, peers, or other role models, such as those provided for by school environments. Social learning has three main requirements. The first is that there must be someone the learner respects and identifies with. The person is called a model. The second requirement is that the child or learner has to observe the model actually behaving in a way he/she has to copy and learn. The final is that the model should visibly experience positive reinforcement for his/her behaviour in the form of experiencing pleasure, or achieveing success and receiving some kind of reward. When children imitate the behaviour of a model, they expect to receive reinforcement first just as the model did.

Bandura (1977) studied the aspect of social learning theory called modeling. He stated that behaviour is learned from the environment through the process of observation, imitation, and modelling. Bandura and Walters (1965) conducted the bobo doll experiment, in which they exposed nursery school children to films of adults, and in some cases, adults behaving aggressively to a large plastic doll. Over time, it was found that this group of children tended to behave toward the doll in the same way that adults did. On the contrary, children 
who were not exposed to such films rarely made such aggressive responses. During the famous bobo doll experiment, Bandura and Walters (1965) reported that children observe the people around them behaving in various ways. Individuals that are observed are called models.

The experiment demonstrated the importance of vicarious consequences in order to make the imitative behaviour possible.

In society, children are surrounded by many influential models, such as parents within the family, characters on children's television, friends within their peer group, and teachers at school. These models provide examples of masculine and feminine behaviour to observe and imitate. They pay attention to some of these people (models) and encode their behaviour. At a later time, they may imitate (i.e., copy) the behaviour they have observed. They may do this regardless of whether the behaviour is deemed appropriate by the society or not. However, in his study of Bandura's work, Mcleod (2011) noted that there are a number of processes that make it more likely that a child will reproduce the social behaviour its society deems appropriate.

First, the child is more likely to attend and imitate those people he/she perceives as similar to himself/herself. Second, the people around the child will respond to the behaviour he/she imitates with either reinforcement or punishment. If the child imitates a model's behaviour and the consequences are rewarding, he/she is likely to continue performing the behaviour. For instance, if a parent sees a little girl consoling her teddy bear and says "What a kind girl you are", this is rewarding for the child and makes it more likely that she will repeat the behaviour because her behaviour has been reinforced or strengthened. Reinforcement can be positive or negative and can be external or internal. Whichever is the case, the important factor is that it should match with an individual's needs and will usually lead to a change in a person's behaviour. Thirdly, the child will also take into account of what happened to other people when deciding whether or not to copy someone's actions. This is known as vicarious reinforcement.

\section{Implication of Bandura's Theory to Child Rearing}

Bandura's theory relates to attachment to specific models that possess qualities seen as rewarding. Children will have a number of models with whom they identify and copy. These may be people in their immediate world, such as parents, extended family members, elder siblings, or could be fantasy characters or people in the media. The motivation to identify with a particular model is that they have the quality the individual would like to possess. This means that children could learn aggressive and violent behaviour through observation of aggression and violence from parents, siblings, extended family members, and television programmes. It also means that if they observe positive behaviours from these sources or their environment, they could emulate such behaviours as well especially if the family or parents reinforce such behaviour. This therefore explains the need for these sources to serve as positive role models. Hence, Denler, Wolsters, and Benzon (2004) reported that children who observed violent acts on prime television showed aggressive behaviour whether or not they were predisposed to behave aggressively. They cautioned that the real concern with the effect of aggressive behaviour learned by observation of incidents of violence is that the learning has been proven to continue through adolescence into adulthood. It follows that a long-term solution to violence in Nigeria is to ensure that children are not exposed to violence and aggressive behaviour in their environment during their infancy. This is because most concepts and principles are cultivated by the individual during this early childhood years (Nwaham, 2006). 


\section{Family Structure, Characteristics, and Child Rearing}

Ukpong (1995) reported that one of the few widely accepted generalizations of social science is that the family is an institution found in every human and non-human society. However, there is a controversy as to what constitutes family and what its function might be. In the social context, the family is regarded as a social group characterized by common residence, economic cooperation, and reproduction. Each normal family is known to comprise the father, mother, and offspring. Webster's Third New International Dictionary (Webster, 1961) defines the family as a set of people comprising the household and all persons in it related by blood or marriage. It is a body of persons who live in one house and under one head, including parents and children. Odede and Egotanwa (2004) defined the family as a group of people who are closely related by blood. Family usually originates from coming together of man and woman through marriage. The main function of the family is to care for its members especially the children. Despite the changing lifestyles and ever-increasing personal mobility that characterize modern society, the family remains the central element of contemporary life. The family offers companionship, security, and a measure of protection against an often uncaring world. But family, like the society at large, has different structures. Differences in life outcomes some have argued, are largely determined by the family, such as its composition and social and economic resources (McLanahan \& Sanderfur, 1994).

One fundamental characteristic of the family that has significant and sustaining effects on children is its structure, i.e., the number of parents and their relationships to the child in the household (Schneider, 2005). Amato (2001) has argued that a family structure can constrain the availability of economic and social resources, such as parents' ability to spend time with their child, be involved in educational activities, and expend monetary resources that can promote positive educational outcomes and well being.

Nwaham (2006) considered childhood as the most important stage of the total development of man and humanity. Thus, he believed that childhood is the formative period in the life of an individual. This implies that most concepts and principles of life are inculcated in the individual during this early childhood years. Hence, there is a need to lay solid foundation for children during the formative period. This may depend on how the child is reared in terms of feeding, cleaning, protection, stimulation, and monitoring growth and development. The role of parents and families in such child rearing practices is very fundamental. Nwaham (2006) has therefore argued that the family environment has great influence on the performance of the parents and children. Hence, parents and caregivers should make the family environment stimulating. Furthermore, when discussing the importance of family and home environment, Nwaham (2006) noted that many children do well in life because their home and family environment have provided them with good care and preparation. Others do poorly because they are discouraged in that regard and other environment like the school has not been successful in overcoming this disadvantage. Blool (as cited in Ezewu, 1984) observed that a child's family and home environment are important in the formation of cognitive abilities which include measured intelligence, creativity, the manner in which the child conducts inter personal relationship, and the level of thinking. The family environment therefore affects the child physically, mentally, emotionally, and socially. Family structure has been consistently found to be the deciding factor in a wide range of child behaviour that directly influences academic performance including emotional and psychological distress, attention disorders, misbehaviours, substance abuse, sexual abuse, and teenage pregnancy (Agbo, 1997). Therefore, given a conducive and appropriate family and home environment, the problem of violence in Nigeria could be given a sustained 
solution using child rearing approach. The following are some of the family structures and characteristics that are known to influence child rearing practices and outcomes.

\section{Family Type}

We shall consider two family types, namely, nuclear family and extended family.

Nuclear family. The nuclear family is the traditional type of family structure. This family type consists of mother, father, and children. The nuclear family was long held in esteem by society as being the ideal in which to raise children. Children in nuclear families receive strength and stability from the two-parent structure and generally have more opportunities due to the financial ease of two adults. According to Perez (2002), almost $70 \%$ of children live in a nuclear family unit. Igbokwe (2014) also reported that $70 \%$ of children in day care centres in Akwa Ibom State live in nuclear families.

Extended family. Another variation of family type is the extended family. The extended family refers to grandparents, aunts, uncles, and cousins. Many extended families include cousins, aunts or uncles, and grandparents living together. This type of family structure may form due to financial difficulties or because older relatives are unable to care for themselves alone. A strong relationship within the extended family can be just as rewarding as close ties inside the nuclear family. However, building those bonds inside the extended family can be a little more difficult because, obviously, everyone does not live under the same roof. Extended families are becoming increasingly common all over the world.

Researchers on traditional child rearing practices in Nigeria have observed that such practices are communal within the extended family system or lineage where even the costs of raising children are shared between biological parents and a close knit of relations in terms of emotions, time, finance, and other material support (Fapounda \& Todaro, 1988; Wusu \& Isiugo-Abanihe, 2006). Right from birth, surrogate mothers, such as mothers-in-law or sisters-in-law from either the husbands or wife's family make themselves available to assist in caring for the newborn baby and the nursing mother. However, this trend in child rearing attitude appears to have significantly changed. For instance, Wusu and Isiugo-Abinihe (2003) reported that in Ogu family in Yoruba, the strong kinship tie that had helped to sustain the extended family structure is steadily growing weaker. There is a gradual weakening of the cord binding the extended family systems and an increasing shift to the nuclear family comprising a man, his wife, and their children, even in rural settings. These changes are weakening the interpersonal relationship among members of a kin group. They identified the reasons for this transformation to include the rate of urbanization and employment opportunities outside the extended family. Young couples are now compelled by circumstances to start their separate homes usually away from their parents, especially in cities and large towns. Extended family members no longer see the assistance they render to relations in child rearing as an obligation. Also, child fostering among kin group members is on the decline. Similarly, the care given by close relatives, such as mothers-in-law when a baby is born is on the decline; where such assistance is given, the period is considerably shorter than what is obtained in the past.

The increasing shift to the nuclear family structure and the involvement of mothers in urban and rural areas in income generating activities in addition to their major role in household management and operations may in addition have the consequence of influencing the care and support provided for the children by virtue of its limited and fluctuating number of adults as a result of seasonal and work-related in-and-out migration. Hence, researchers have found that parents of children from extended family system do better in child rearing practices than their nuclear family counterparts (Wusu \& Isiugo-Abanihe, 2006; Igbokwe, 2014). 


\section{Parent Type}

Parent type in the context of this discussion defines the family of the child as either a single-parent family, a two-parent family with a mother and a father, or a step-parent family.

Two-parent family. The concept of marriage is as old as mankind, whether in primitive, traditional, or modern society. It is the wish of every adult to get married and procreate. In a typical African society, the general expectation is that the marriage will be blessed with children and the general welfare of the offspring is supposed to be a joint responsibility between the spouses. This general welfare includes among others provision of clothing, shelter, and bringing up the child in a socially acceptable manner in line with the norms and values of the society. Inability of families or parents to provide these basic social and psychological needs for children often lead to frustration, depression, poor school attainment, and manifestation of various forms of maladaptive behaviours (Ojo, 2000) that often lead to development of aggression and violence latter in the life of such children. The provision of these basic needs of the children requires the physical presence of both father and mother if it must be effectively carried out. This therefore shows that parents have an important role to play in child upbringing. When there is a vacuum in this regard, children are exposed to a variety of psycho-social or emotional problems that ultimately affect the society.

Obot (1995) in a study of effect of family childhood socialization on the social adjustment of the child in selected nursery schools in Calabar Municipality noted that social learning theory suggests that parents may be important socializing agents and role models for the growing child. The children brought up from intact family or warm extended family relations in a conducive environment would be open minded, loving, caring and fair to all. They would perceive themselves as being loved and would make friends easily with other children. On the other hand, the child who perceives other adults as being "bad" will be insecure, suspicious and fail to trust anyone.

Single-parent family. Wusu and Isiugo-Abanike (2006) observed that a major family structure in Nigeria is the emergence of single-parenting or one-parent households with a group of urban women who remain unmarried, but have children from their lovers while some one-parent households result from divorce, separation, or death of spouse. They lamented that the number is large, growing, and becoming a common phenomenon especially among urban women. Whatever a particular family structure is, it is likely to have tremendous influence on the parents' child rearing practice and upon the baby's happiness, development, and future. Furthermore, Eiduson (1990) pointed out that the plight of a single parent in which a change of family status brought about by divorce, death, or desertion results in sharp downward economic mobility, which is often compounded by poor housing and sometimes the parents move into deterioration and high-stress neighbourhood. Such parents are solely in charge of decision-making, finances, bread-winning, and monitoring. They therefore often feel fatigue and depression. Single parents are stressed with heavy work involved in providing psychological and personal supports for children which may affect the parents' child rearing practice as they work outside the home most of the time leaving the children in the hands of maids without adequate care.

Often, a single-parent family is a mother with her children, although there are single fathers as well. The single-parent family is the biggest change that the society has seen in terms of the changes in family structures. Tor-Anyim and Bark (2006) reported that one in four children is born to a single mother. Single-parent families are generally close and find ways to work together to solve problems, such as dividing up household chores. 
When only one parent is at home, it may be a struggle to find childcare, as there is only one parent working. This limits income and opportunities in many cases, although many single-parent families have help from relatives and friends.

Tor-Anyim and Bark (2006) stressed that single parenthood breeds violence-related problems, like aggression, rage, maiming, and drug abuse. Woldkind and Reuther (1995) also observed that the living standard of children in single-parent fanilies is negatively affected because the resources have been reduced drastically. In a related development, Said (2006) demonstrated that school attainment of children from single-parent homes tends to be undermined because the socioeconomic background is a strong factor in the academic achievement of children.

It has been reported that children from single-parent families scored lower than full parents children in various moral indices (Hoffruan, 1971). Harrison (1995) stated that the emotional effects of single parenthood are quite devastating and characterized by depression, grief, sadness, and loneliness. Ojo (2000) also asserted that single-parent children in schools are often found to exhibit traits of unhappiness among their peers. They are usually withdrawn from the crowd, and so perform low in team-work and classroom activities and these tend to affect their academic performance in school.

Step-parent family. Sometimes, divorced parents eventually remarry. Similarly, many women who have had a non-marital birth eventually marry men who are not the fathers of their children. Adding a stepfather to the household usually improves children's standard of living. Moreover, in a stepfamily, two adults are available to monitor children's behavior, provide supervision, and assist children with everyday problems. For these reasons, one might assume that children generally are better off in stepfamilies than in a single-parent household. Studies consistently indicate, however, that children in stepfamilies exhibit more problems than do children with continuously married parents and about the same number of problems as do children with single parents. In other words, the marriage of a single parent (to someone other than the child's biological parent) does not appear to improve the functioning of most children. In fact, parental separation has been reported in the literature as being associated with a wide range of adverse effects on children's wellbeing, both as a short-term consequence of the transition and in the form of more enduring effects that persist into adulthood (Mackay, 2005). Effects reported include adverse impacts on cognitive capacity (Fergusson, Lynskey, \& Horwood, 1994), schooling (Evans, Kelley, \& Wanner, 2001), physical health (Dawson, 1991), mental and emotional health (Chase-Lansdale, Cherlin, \& Kiernan, 1995), social conduct and behaviour (Morrison \& Coiro, 1999), peer relations (Demo \& Acock, 1988), criminal offending (Hanson, 1999), cigarette smoking (Ermisch \& Francesconi, 2001), substance use (Fergusson et al., 1994), early departure from home (Mitchell, Wister, \& Burch, 1989), early-onset sexual behaviour (Ellis et al., 2003), and teenage pregnancy (Woodward, Fergusson, \& Horwood, 2001).

A further range of impacts in early adulthood and beyond include higher rates of early childbearing (McLanahan \& Bumpass, 1994), early marriage (Keith \& Finlay, 1988), marital dissolution (Amato \& DeBoer, 2001), lone parenthood (McLanahan \& Booth, 1989), low occupational status (Biblarz \& Gottainer, 2000), economic hardship (McLanahan \& Booth, 1989), poor-quality relationships with parents (Aquilino, 1994), unhappiness (Biblarz \& Gottainer, 2000), discontentment with life (Furstenberg \& Teitler, 1994), mistrust in others (Ross \& Mirowsky, 1999), and reduced longevity (Tucker et al., 1997).

Generally, stepchildren are overrepresented in official reports of child abuse. Two-parent family does significantly better in child rearing practices than single-parent and step-parent families (Igbokwe, 2014) 


\section{Education and Occupation}

Research evidence has shown that the better educated the mother, the more likely her children are to attend and remain at school to be healthier and have better nutrition (United Nations International Children's Emergency Fund (UNICEF), 1996). Ehiemetalor (1982) and Oladele (1987) reported that the mother's level of education is one of the most important factors influencing children's reading levels and other school achievement. Supporting this idea, Ezewu (1984) asserted that well-educated parents were likely to provide both financial and material support to ensure their children's progress. Furthermore, children whose parents provide structured supervised activities tend to do better in cognitive tests and earn better grades.

Akinsanya, Ajayi, and Modupe (2010) investigated the relative effects of parents' occupation, education, and academic motivation of wards on students' achievements in senior secondary school mathematics in Ogun State, Nigeria. The result reveals that parents' education has the highest significant influence on the academic achievement of students in mathematics while the effect of academic motivation had the least effect among the variables which exerted significant effects on students' academic achievement in mathematics. From the above findings, it is therefore likely that generally mother's level of education and occupation influence her child rearing practices also.

\section{Birth Order}

Birth order refers to the chronological position of the child among the child's siblings. Chen and Escarce (2006) reported that birth order is sufficient to capture the effect of parental child rearing experience if the way parents seek care for a particular child is influenced by what they learn from rearing that child's older siblings.

Historically, first-borns are their parents "blue-chip security", whose birth is most eagerly anticipated, whose first steps, first words, and first everything are celebrated. Fapounda and Todoro (1988) remarked that typical first-borns are "approval seeking missiles", have been less likely to die in infancy, are less susceptible to disease, and as adults, are more likely to reproduce. They have been showered with attention and identify strongly with power. First-borns are thought to be conscientious and achievement-oriented. Schilmoeller and Baranowski (1985) reported that a study of Norwegians born between 1912 and 1975 found that educational achievement was the highest in first-borns and diminished the further down the birth order despite little difference in intelligence quotient (IQ).

\section{Number of Steady Adults}

Chen and Escarce (2006) in their study observed that children living with three or four or more other adults or much older siblings received less child rearing attention than adult children living with no, one, or two other adults. They also investigated the use of ambulatory visits and prescription medication. Among other things, they found out that children living in the family with many other children or adults use less ambulatory care and prescription medication than their peers. They concluded that children's health and well-being are intimately linked to the structure of their families. Hence, family size and number of siblings also affect children's outcome and well-being.

\section{Family Location}

Kendall (2007) compared non-parental care arrangements of pre-school age children in urban and rural areas of the United States. The result showed that among preschool-age children, those in rural areas are about as likely as those in urban areas to receive care from someone other than their parents on a weekly basis; and 
that when rural children participate in non-parental care, they are more likely than urban children to receive this care from relatives. Similarly, Igbokwe (2014) reported that parents of children in day care centres in urban areas in Akwa Ibom State, Nigeria, do better in child rearing practices than their rural area counterparts.

\section{Age of Parents}

Similarly, some researchers (Fapounda \& Toddoro, 1988; Brown, 2004; The Urban Institute, 2006) have provided evidence to show that the age of parents could be a factor in child rearing. They observed that parents who have children later in life face several advantages and disadvantages. On the plus side, they are most likely to be more financially stable, secure in their job and home, and clear about what they want. But they probably have less energy than their younger counterparts. On the other hand, parents who have children in their teens may face a variety of problems. First, there may be some social stigma attached to having a child at such an early age. Without the support of their family and friends, the new parents will most likely not get the financial and emotional support they need for proper child rearing.

Agusiobo (2000) investigated the child rearing practices of women in rural and urban areas. The researcher found out that over $50 \%$ of mothers within the suitable child bearing age range (26-30 years) had access to health care facilities. The incidence of teenage mothers although low was predominant in rural areas of Northern States. Such mothers were susceptible to some life threatening diseases. Malaria affected over 50\% of mothers and it remained the principle cause of maternal morbidity. Others were diarrhea, typhoid, cholera, and guinea worm.

Similarly, some women bear additional children in their middle years of life or have their first child after the age of 35. Fapounda and Todaro (1988) have pointed out that having a first child in middle life has some positive aspects. For instance, such parents would have about 15-20 years of adult life experience and so have more inner resources to draw on in times of stress than a younger parent does. Moreover, having had many experiences, many middle-age adults are ready to be parents, have a sense of renewal and identity, have a deeper sense of the value of life itself, and so tend to place high value on the time they can spend with their children. In particular, such parents are usually at the height of their earning power, so they have more financial stability to support a child.

On the other hand, they noted that while many of the positive things about having a baby in midlife involve the joy of raising a small child, there are obvious drawbacks and concerns which have mostly to do with the future and with the parents' concerns about aging, such as having lower energy level to be as active as their child needs them to be; the worry as to whether they will live to see their grandchildren or even see their child become an adult. Will they very quickly become a burden to a child just as he/she is trying to get on his/her feet as a young adult? Fapounda and Todaro (1988) remarked that when the age difference is 40 or more years, quite a schism is created; parents worry whether their values will be at all relevant to their child. Such age difference may be particularly apparent when a child becomes a teenager - a difficult period for even young parents to deal with.

There are positives and negatives to have a first child in midlife. Although it is not uncommon for women to bear additional children in their middle years, it was once quite uncommon for a woman to have her first child after the age of 30. Today, many women choose not to have a child until they are in their 30s. The reasons for this are many. Many couples choose to become established in their lives and careers before turning their thoughts to childbearing. Many see 20 s as a time to experiment and experience freedom. At that age, some women and men do not feel psychologically ready for the commitment of having children. Some single women 
may have such high expectations for themselves and others that they are unable to find mates who meet their qualifications for fatherhood. Though these women might opt out to have children sooner, they often do not find a suitable situation for doing so until they are older. And then, there are couples who, for some reasons, appear to be biologically unable to conceive until when they are just about giving up, they finally conceive.

Schilmoeller and Baranowski (1985) reported that adolescent mothers scored significantly lower than older mothers on a measure of overall stimulation provided for the infant. Also, adolescents relied more on relatives and their mothers for help and information about childcare, while older mothers turned more often to friends.

\section{Class Status}

Ezewu (1984) remarked that children from deprived social background lagged behind in most aspects of school learning as parents find it difficult to provide financial and material aids for the education. Wortis, Bardach, Cutler, Rue, and Freedmanal (1963) reported that elements in the environment that prepare the child to take over a lower class role include inadequate incomes, crowded homes, lack of consistent familial ties, and the mother's depression and helplessness in her own situation, were as important as her child rearing practices in influencing the child's development and preparing him/her for an adult role. Wortis et al. (1963) actually lamented their sobering experience to watch a large group of newborn infants, human beings of unknown potential, and to observe over a five-year period their social preparation to enter the class of the least-skilled, least-educated, and most-rejected in their society. These findings support the view that there are characteristics in child rearing practices which are related to class status, and that these differences become more pronounced with the extremes of class. They therefore suggested ways of promoting child rearing practices that will reduce the effect of class distinction and enhance desirable affective behaviour in children to include:

(a) Demonstration of warmth physically and sharing of play experiences with children;

(b) Not neglecting children, as doing otherwise leads children to frustration, aggression, and negative attitude towards life;

(c) Setting good examples since children model their parents;

(d) Adopting child-centered approach at home to encourage children to be resourceful, self-reliant, and socially well-adjusted.

On a final note, we remark that the family is the most prominent social group that exists. It prepares its members for the various roles they will perform in society. Yet, the literature has unequivocally singled out the family as the most violent social group, with parental violence against children being the most prevalent type of family violence in Nigeria. While societies, like the United States, Japan, and Sweden, have taken a hard line on physical punishment and shifted to a gentler approach to discipline, harsh disciplining of children and poor child rearing practices persist in Nigeria. In Nigeria, child rearing and disciplinary practices that would warrant child abuse charges in other Western societies are rampant. For instance, Bukoye (2004) (as cited in Nwankwo, 2011) has decried the parent-child relationship in some Nigerian families, in which incidences of child neglect and abuse, such as excessive corporal punishment in the name of discipline, emotional abuse, social neglect, and even gender discrimination, are of common place in the family. Rearing children under such violent environment, especially when such violence is perpetrated by parents themselves, presents such children with negative models that lead to severe anti-social behaviour, like aggression and violence later in their life. 


\section{Conclusion}

This article has brought to the fore the importance of child rearing practices and some of those family variables that could significantly influence effective child rearing practices. Violent or aggressive role models, single- and step- parenting environments, low educational and class status, and child rearing during infancy are some of the factors associated with a wide range of adverse effect on children's well-being. The adverse effects are enduring, persist into adolescence and adulthood, and ultimately could lead to varied anti-social behavior, like aggression or violence in the individual. To avert these requires that parents should give their families a positive tone for effective child rearing in the interest of the society. This is because our future rests in the hands of the children we raise. A child cannot care for or nurture others if he/she is not cared for or nurtured first. Children who mature without their basic needs significantly met become adults incapable of giving unconditional love, support, and sympathy. Such people have the tendency to work against the norms and values of the society and constitute notable source of violence.

\section{Recommendations}

To ensure sound child rearing practices that will guarantee a violent-free culture in Nigeria in the long run, the following recommendations are necessary:

1. Parents should as much as possible take advantage of the services and assistance obtainable from the extended family system in enhancing their child rearing practices;

2. Interventions and family life programmes that could increase the number of children reared by continuously married biological parents should be mounted, encouraged, and intensified by government, churches, and social welfare societies and communities through marriage courses, awareness programmes, and other services. Such interventions should be geared toward strengthening marriages, decreasing the rate of divorce, and improving the well-being of families so as to decrease mortality rate of parents; and hence, reducing the number of single-parent and step-parent families which are known to breed wide range of aggression and violence related problems both in the short and long run;

3. Social welfare centres, government, and some non-governmental organizations and schools should pay special attention to children growing up in single-parent and step-parent families since the weight of research evidence suggests that such families increase children's risk of a variety of cognititve, emotional, and social problems because of poor child rearing practices by their families and parents;

4. For effective child rearing practices, parents should strictly adhere to the recommendations of WHO (2000) on "Improving Children's Health and Nutrition in Communities";

5. It is likely to be of significant benefits for the well-being of the children if separated couples should be helped through some counselling and awareness programmes to reduce levels of conflict following separation or at least to understand the importance of conducting their affairs out of the way of the children and in ways that do not implicate them;

6. Government should ensure the availability of good social amenities, such as hospitals and health centres, water and electricity, etc., in the rural areas as obtainable in the urban centres. This will help improve child rearing practices of parents in families in rural locations. Campaigns on good child rearing practices should also be regularly mounted for parents;

7. Mothers should be committed to improving their educational status since this has the likelihood of 
imparting on their child rearing practices and the overall well-being of their families;

8. Familiy members, teachers, and others should always ensure that they serve as good or positive role models to the children in their environment and parents should censor those models the children observe in their environment to ensure that they imitate positive behaviours;

9. Families should discourage teenage marriage because of its negative consequences on child rearing practices;

10. The contents of social studies and early childhood education curricula in schools should be enriched with the tenets of good child rearing practices and the findings on how family structure influences child rearing practices. Such contents should among others include the recommendations of WHO (2000) on "Improving Children's Health and Nutrition in Communities".

\section{References}

Abayomi, F. (2003). The press in Nigeria's emerging democracy: The challenges of a new era. In K. Ajayi, \& B. Ayodele (Eds.) (2004), Perspectives on democracy and development in post-military Nigeria (p. 136). Ibadan: Julius and Julius Associate.

Africa Report. (2014). Report Title. Retrieved from http://www.theafricareport.com/Africa-in-2014.html

Agbo, J. A. (1997). Effects of delinquent environment on academic achievement of primary six pupils in army children's school aware. The Nigerian Teacher Today, A Journal of Teacher Education, 5(21), 105.

Agusiobo, A. M. (2000). African child rearing practices: Outlook for the new century. Proceedings of The OMEP Africa Regional Seminar (pp. 121-131).

Akinsanya, O. O., Ajayi, K. O., \& Modupe, S. O. (2010). Relative effects of parents' occupation, qualification and academic motivation of wards on students' achievement in senior secondary school mathematics in Ogun State. Journal of Science and Education, 4, 106-113.

Amato, P. (2001). Children of divorce in the 1990's: An update of the Amato and Keith (1991) meta-analysis. Journal of Family Psychology, 15, 355-370.

Amato, P. R., \& Danelle, D. D. (2001). The transmission of marital instability across generations: Relationship skills or commitment to marriage? Journal of Marriage and Family, 63, 1038-1051.

Aquilino, W. S. (1994). Impact of childhood family disruption on young adults' relationships with parents. Journal of Marriage and Family, 56(2), 295-313.

Armar-Klemesu, M., Reul, M. T., Maxwell, D. G., Levin, C. E., \& Morris, S. S. (2000). Poor maternal schooling is the main constraint to good, childcare practices in Accra. Journal of Nutrition, 130, 1597-1607.

Arnold, F., Bulatao, R. A., Buripkdi, C., Chung, B. J., Fawcett, J. T., Iritani, T., ... Wo, T. (1975). The value of children: A cross national study. Honolulu, Hawaii: East West Population Institute.

Bandura, A. (1977 ). The social learning theory. Eaglewood Cliffs, N.J.: Prentice Hall.

Bandura, A., \& Walters, R. (1965). Social learning and personality development. New York, N.Y.: Holt, Rinehart and Winston.

Baumrind, D. (1966). Effect of authoritative parenting control in child behavior. Child Development-JSTOR, 37(4), 887-907.

Biblarz, T. J., \& Gottainer, G. (2000). Family structure and children's success: A comparison of widowed and divorced single-mother families. Journal of Marriage and Family, 62(2), 533-548.

Bornstein, M. H. (2002). Handbook of parenting (2nd ed., pp. 381-388). Mahwah, N.J.: Lawrence Eribaum Asssociates.

Brown, S. L. (2004). Family structure and child well-being: The significance of parental cohabitation. Journal of Marriage and Family, 66(2), 351-367.

Bruer, J. T. (1999). The myth of the first three years. New York, N.Y.: Free Press.

Bukoye, R. O. (2004). Attitude of parents towards child abuse. The Counselor, 20(1), 144-152.

Campbell, L. (2014). The hierarchy of needs in babies demand media. Retrieved October 6, 2014, from http://everydaylife.globalpost.com/hierarchy-needs-babies-12183.html

Centre for Law Enforcement Education (CLEEN) Foundation. (2014). Domestic violence in Nigeria. In Wikipedia, the Free Encyclopedia. Retrieved October 7, 2014, from http://en.wikipedia.org/wiki/Domestic_violence_in_Nigeria 
Chase-Lansdale, P. L., Cherlin, A. J., \& Kiernan, K. E. (1995). The long-term effects of parental divorce on the mental health of young adults: A developmental perspective. Child Development, 66, 1614-1634.

Chen, A. Y., \& Escance, J. J. (2006). The effect of family structure on children's use of ambulatory and prescription medications. Health Services Research, 41(5), 1895-1914. doi: 10.111/j.1475-6773. 2006.00584.x5.7.2012

Darling, N., \& Steinberg, L. (1993). Parenting style as context: An integrative model. Psychological Bulletin, 4(2), $220-231$.

Dawson, D. A. (1991). Family structure and children's health and well-being: Data from the 1988 national health interview survey on child health. Journal of Marriage and Family, 53, 573-584.

Demo, D. H., \& Acock, A. C. (1988). The impact of divorce on children. Journal of Marriage and Family, 50(3), 619-648.

Demo, D. H., \& Acock, A. C. (1996). Family structure, family process, and adolescent well-being. Journal of Research on Adolescence, 6(4), 457-488.

Denler, H., Wolters, C., \& Benzon, M. (2014). Television: Friend or foe? Social cognitive theory. Retrieved October 10, 2014, from http://www.education.com/reference/article/social-cognitive -theory/

Ehiemetalor, E. T. (1982). Provision of facilities for parents. Lagos: UniPress Inc..

Eiduson, K. (1990). Cognitive matters. In T. R. Murray (Ed), The encyclopaedia of human research and studies. Los Angeles, C.A.: Zera Press.

Ellis, B. J., Bates, J. E., Dodge, K. A., Fergusson, D. M., Horwood, L. J., Pettit, G. S., \& Woodward, L. J. (2003). Does father absence place daughters at special risk for early sexual activity and teenage pregnancy? Child Development, 74(3), 801-821.

Enweremadu, D. U. (2014). Ending the vicious circle: Oil, corruption, and violent conflict in the Niger Delta (p. 20). Retrieved October 9, 2014, from http://www.ifra-nigeria.org/publications/ifra-e-papers/article/ifra-conference-on-conflict-and

Ermisch, J. F., \& Francesconi, M. (2001). Family structure and children's achievements. Journal of Population Economics, 14, 249-270.

Evans, J. L., \& Myers, R. G. (1994). Child rearing practices: Creating programmes where traditional and modern practices meet. The Consultative Group on Early Childhood Care and Development, Coordinators' Notebook, 15, 1-22. Retrieved from http://www.ecdgroup.com/download/cc115aci.pdf

Evans, M. D. R., Kelley, J., \& Wanner, R. A. (2001). Educational attainment of the children of divorce: Australia, 1940-90. Journal of Sociology, 37(3), 275-297.

Ezewu, E. (1984). Sociological and philosophical foundations of education. Ibadan: Heinemann Educational Books Nigeria Ltd..

Fapounda, R. E., \& Todaro, P. M. (1988). Family structure, implicit contacts and demand for children in southern Nigeria. Population and Development Review, 11(1), 53-72.

Fergusson, D. M., Lynskey, M. T., \& Horwood, L. J. (1994). The effects of parental separation, the timing of separation and gender on children's performance on cognitive tests. Journal of Child Psychology and Psychiatry, 35(6), 1077-1092.

Furstenberg, F. F., \& Teitler, J. O. (1994). Reconsidering the effects of marital disruption: What happens to children of divorce in early adulthood? Journal of Family Issues, 15(2), 173-190.

Hanson, T. L. (1999). Does parental conflict explain why divorce is negatively associated with child welfare? Social Forces, 77(4), $1283-1315$.

Harris, J. R. (1988). The mature assumption: Why children turn out the way they do. Parents matter less than you think and peers matter more. New York, N.Y.: Free Press.

Harrison, Y. B. (1995). Single parenthood and youth in Sub-Saharan Africa. Addis Ababa: Ethiopia Publications.

Hetherington, E. M., \& Kelly, J. (2002). For better or for worse: Divorce reconsidered. New York, N.Y.: Norton.

Hoffman, L. W. (1963). Mothers employment and effects on child. In F. I. Nye, \& L. W. Hoffman, (Eds.), The employment of mothers in America. Chicago, I.L.: Acad Publishers Inc..

Hoffruan, M. L. (1971). Father and conscience development. Development Psychology, 51, 400-406.

Igbokwe C. O. (2014). Family structures and child rearing practices of parents of children in day care centres in Akwa Ibom State (Unpublished Ph.D. dissertation, University of Uyo).

Iliya, H. (2000). Child rearing practices of the Mupun and their effects on school performance. Journal for Early Childhood Education, 2, 33-38.

Keith, V. M., \& Finlay, B. (1988). The impact of parental divorce on children's educational attainment, marital timing, and likelihood of divorce. Journal of Marriage and Family, 50, 797-809.

Kendall, S. (2007). Child care arrangements in urban and rural areas. Planning and Evaluation Office of U.S. Department of Health and Human Services. 
Mackay, R. (2005). The impact of family structure and family change on child outcomes: A personal reading of the research literature. Social Policy Journal of New Zealand, 24, 111-133. Retrieved October 10, 2014, from https://www.msd.govt. nz/about-msd-and-our-work/publications-resources/journals-and-magazines/social-policy-journal/spj24/24-impact-of-familystructure-and-family-change-on-child-outcome-p111-133.html

Maslow, A. H. (1970). Towards a psychology of a being. Princeton, N.J.: Nostrand.

McLanahan, S., \& Booth, K. (1989). Mother-only families: Problems, prospects, and politics. Journal of Marriage and Family, 51(3), 557-580.

McLanahan, S., \& Bumpass, L. (1994). Intergenerational consequences of family disruption. American Journal of Sociology, 1, 130-152.

McLanahan, S., \& Sanderfur, G. (1994). Growing up with a single parent: What hurts, what helps. Cambridge, M.A.: Harvard University Press.

McLeod, S. A. (2011). Bandura social learning theory. Retrived from http://www.simplypsychology.org/bandura.html

Mitchell, B. A., Wister, A. V., \& Burch, T. K. (1989). The family environment and leaving the parental home. Journal of Marriage and Family, 51(3), 605-613.

Morrison, D. R., \& Coiro, M. J. (1999). Parental conflict and marital disruption: Do children benefit when high-conflict marriages are dissolved? Journal of Marriage and Family, 61, 626-637.

Nigeria Security Tracker (NST). (2014). Mapping violence in Nigeria. Retrieved October 10, 2014, from http://www.cfr.org/nigeria/nigeria-security-tracker/p29483 http://jide-salu.com/2014/01/09/nigeria-security-tracker-jide-salu/

Nigeria Watch. (2012). Third report on violence in Nigeria (2006-2011). Retrieved October 13, 2014, from http://www.nigeriawatch.org/media/html/NGA-Watch-Report11\%281\%29.pdf

Nwaham, C. O. (2006). Academic competence of pre-primary school children: Influence of families. Journal of Childhood and Primary Education, 2(1), 128-135.

Nwankwo, F. M. (2011). Child abuse and social adjustment of public primary school pupils in Abia State. Journal of Education, $4(1), 80-91$.

Obot, A. E. (1995). Effect of family childhood socialization on the social adjustment of the child in selected nursery schools in Calabar Municipality. JOCROMEP, 1(1), 49-56.

Odedele, M. O. A., \& Egotenwa, M. C. (2004). Basic facts in general social studies for junior secondary schools. Onitsha: Elites Commercial Agency Ltd..

Ojo, O. D. (2000). Solo and double parental on the adjustment problem of secondary school adolescent. Nigerian Journal of Counseling, 1(1), 81-92.

Oladele, J. O. (1987). Fundamentals of psychological foundations of education. Lagos: Johns 2nd Enterprise Publishers.

Perez, W. Z. (2002). Categorization of single parenthood status, the indices of frequency in Paris: A guide for vital public health making. Journal of World Health Organization, 16(11), 70-88.

Prescott, K. P. (2010). Issues in child rearing. Journal of Early Life, 23(4), 231-242.

Reeve, P. (1992). Characteristics of mothers and fathers job: Implication for parenting and children social behavior. Journal of Research, 12(3), 241-250.

Rohwer, W. D., Rohwer, G. R., \& Howe, J. R. (1980). Educational psychology. New York, N.Y.: Holt, Rinehart and Winston.

Ross, C. E., \& Mirowsky, J. (1999). Parental divorce, life-course disruption, and adult depression. Journal of Marriage and Family, 61, 1034-1045.

Said, Z. M. (2006). Effects of single parenthood on academic achievements of secondary school students in Kombotso L. G. A., Kano State (Unpublished PGDE Project, Federal College of Education, Kano).

Saramma, P. P., \& Thomas, S. V. (2010). Child rearing knowledge and practice scales for women with epilepsy. Annals of Indian Academy of Neurology, 13(3), 171-179. doi: 10.4103/0972-2327.70877

Schilmoeller, G. L., \& Baranowski, M. D. (1985). Child rearing of firstborns by adolescent and older mothers. Adolescence, 20(80), 805-822.

Schneider, B. (2005). Parents, their children and schools. Boulder, C.O.: Westview Press.

The Urban Institute. (2006). Parents and children facing a world of risk: Next step towards a working family's agenda. Retrieved May 7, 2013, from http://www.urban.org/uploadPDF/311288parentsandchildren.pdf

Tor-Anyim, S. A., \& Bark, J. L. (2006). Influence of single parenthood and aggression of offsprings in Benue State. The Counsellor, 22, 1-10.

Tucker, J. S., Friedman, H. S., Schwartz, J. E., Criqui, M. H., Tomlinson-Keasey, C., Wingard, D. L., \& Martin, L. R. (1997). Parental divorce: Effects on individual behavior and longevity. Journal of Personality and Social Psychology, 73(2), 381-391. 
Ukpong, E. N. (1995). Personality traits of pre-school children from single-parent and normal families. JOCROMEP, 1, 84-94.

United Nations International Children's Emergency Fund (UNICEF). (1994). Educating and empowering parents to enhance early childhood development: An integrated strategy of the municipal level in Chile, Santiago Chile. New York, N.Y.: UNICEF.

Vangard. (2014, September 3). Attacks, abductions: An upsurge in violence in Nigeria. Retrieved from $\mathrm{http} / /$ www.vanguardngr.com/2014/09/attacks-abductions-upsurge-violence-nigeria/\#sthash.QFDGfRnP.dpuf

Webster, M. (1961). Webster's third new international dictionary. U. K: Encyclopedia Britannia Inc..

Wendorf, K. (2004, March). Our child, not mine ending the parent blame-game. Kindred Magazine, 9, 4.

Woldkind, S., \& Reuther, M. (1995). Separations, loss and family. New York, N.Y.: Gulliford Press.

Woodward, L., Fergusson, D. M., \& Horwood, L. J. (2001). Risk factors and life processes associated with teenage pregnancy: Results of a prospective study from birth to 20 years. Journal of Marriage and Family, 63, 1170-1184.

World Health Organization (WHO). (2000). Improving children's health and nutrition in communities: Indicators for monitoring early childhood. Geneva, Switzerland: WHO.

Wortis, H., Bardach, J. L., Cutler, R., Rue, R., \& Freedman, A. (1963). Child-rearing practices in a low socioeconomic group: The mothers of premature infants. Journal of the American Academy of Pediatrics, 5(3), 253-262. Retrieved from http://pediatrics.aappublications.org/content/32/2/298.short

Wusu, O., \& Isiugo-Abanihe, U. C. (2003). Family structure and reproductive health decision-making among the Ogu of south-western Nigeria: A qualitative study. African Population Studies, 18(2), 27-45.

Wusu, O., \& Isiugo-Abanihe, U. C. (2006). Interconnections among changing family structure, childrearing and fertility behaviour among the Ogu, southwestern Nigeria: A qualitative study. Demographic Research, 1. doi: 10.4054/DemRes.2006.14.8 Retrieved from http://www.researchgate.net/publication/26566024 